\title{
PENINGKATAN ANTUSIASME SISWA KELAS V BELAJAR MATERI PANAS DAN PERPINDAHANNYA MELALUI MULTIMEDIA LINIER
}

\author{
Lisa'yiha Rodhiyah ${ }^{1}$, I Nyoman Sudana Degeng ${ }^{2}$, Eka Pramono Adi ${ }^{3}$ \\ Jurusan Teknologi Pendidikan, Fakultas Ilmu Pendidikan, Universitas Negeri Malang \\ Jalan Semarang 5 Malang $651450341-574700$ \\ Lisayiha.rodhiyah123@gmail.com
}

\section{Article History}

Received:12 Agustus 2020, Accepted: 19 November 2020, Published: 26 Februari 2021

\begin{abstract}
Abstrak
Penelitian ini bertujuan untuk mengembangkan multimedia linier yang layak, serta untuk mengetahui peningkatan antusiasme siswa dalam belajar. Dalam hasil penelitian membuktikan bahwa, pengembangan multimedia linier dapat memenuhi standar kelayakan bila digunakan untuk menunjang proses pembelajaran. Hasil penilaian yang diberikan oleh ahli media dan ahli materi diperoleh dengan hasil kategori layak dan hasil penerapan media untuk siswa termasuk dalam kategori layak. Berdasarkan hasil analisis indikator antusiasme, terdapat perbedaan peningkatan antusiasme belajar siswa antara sebelum dan sesudah menggunakan Multimedia Linier. Peningkatan indikator terbesar terdapat pada konsentrasi, keterlibatan diri pada siswa dan perhatian saat belajar. Dalam hal ini penggunaan Multimedia Linier merupakan salah satu alat perantara belajar siswa untuk memahami materi yang dipelajari dan dapat memberikan pengaruh positif terhadap antusiasme dan motivasi dalam proses pembelajaran.
\end{abstract}

Keyword: Pengembangan; Multimedia Linier; Antusiasme Belajar.

\begin{abstract}
This study aims to develop a feasible linear multimedia, as well as to determine the increase in student enthusiasm in learning. The research results prove that linear multimedia development can meet the feasibility standard when used to support the learning process. The results of the assessment given by media experts and material experts were obtained with the results of the feasible category and the results of applying the media to students in the feasible category. Based on the results of the enthusiasm indicator analysis, there are differences in the increase in student enthusiasm for learning between before and after using Linear Multimedia. The biggest increase in indicators is concentration, self-involvement in students and attention while learning. In this case, the use of linear multimedia is an intermediary tool for student learning to understand the material being studied and can have a positive influence on enthusiasm and motivation in the learning process.
\end{abstract}

Keyword: Development; Linear Multimedia; Enthusiasm for Learning. 


\section{PENDAHULUAN}

Perubahan pendidikan saat ini mengalami kemajuan yang sangat pesat, terutama dalam hal penyampaian materi yang akan dibawakan oleh guru. Banyak perbedaan-perbedaan yang beragam terhadap perkembangan di zaman dahulu dengan zaman sekarang. Semakin banyak ide-ide inovasi dari manusia yang berkembang menjadi lebih praktis dan Efisien. Awal mula dari perkembangan pesat ini karena masalah kehidupan manusia yang sangat berbeda antara satu dengan yang lainnya. Sehingga muncul lah bermacam-macam inovasi untuk kehidupan yang akan datang. Salah satu lahirnya inovasi menarik di zaman ini ialah karena siswa Mendapatkan sebuah pendidikan dan dorongan yang dipenuhi berbagai macam ilmu pengetahuan yang luas, sehingga mereka mampu mendukung pembangunan bangsa dan memecahkan permasalahan pendidikan maupun permasalahan di kehidupan yang dihadapinya di masa depan.

Tujuan Pendidikan dapat tercapai dan berkualitas jika di dalam diri para siswa mempunyai rasa Antusiasme yang tinggi terhadap pentingnya pendidikan bagi setiap individu. (Portzline, 2012) menyebutkan bahwa antusiasme berperan sebagai passion (gairah) atau bliss (kebahagian). Antusiasme memang erat kaitannya dengan gairah atau semangat dan kebahagiaan. Seseorang yang memiliki antusiasme bisa ditandai dengan adanya semangat dan kemauan yang besar untuk mencapai sesuatu. Antusiasme juga akan membuat seseorang dengan senang hati melakukan setiap tugas atau pekerjaan yang diberikan. Lain halnya menurut (Sumiah, 2012) antusias disini merupakan bentuk sikap keterkaitan dengan suatu kegiatan karena menyadari pentingnya kegiatan tersebut. Siswa dikatakan memiliki antusias belajar apabila ketertarikan terhadap materi yang diajarkan oleh guru berusaha melibatkan siswa dalam kegiatan yang berkaitan dengan proses pembelajaran yang berlangsung. Apabila siswa yang memiliki rasa Antusiasme tinggi maka ia akan lebih percaya diri dan terdorong untuk bersemangat mengikuti seluruh proses pembelajaran. Rasa Antusiasme yang tinggi akan menyebabkan terjadinya suatu perubahan energi yang ada pada diri manusia, yang biasanya berkaitan dengan perasaan, gejala kejiwaan dan juga emosi untuk melakukan sesuatu. Sehingga terbesit dalam hati siswa untuk melakukan tujuan dan kebutuhan tersebut demi mendapatkan pengetahuan yang baru dipelajari.

Penggunaan media pembelajaran diharapkan mampu menciptakan suasana proses pembelajaran yang aktif, efektif dan efisien sehingga dapat memberikan perwujudan tujuan pendidikan yang telah di tentukan sebelumnya. (Nurseto, 2011) mengungkapkan bahwa kegunaan media pembelajaran berfungsi sebagai alat mempercepat proses belajar dan dapat meningkatkan kualitas belajar agar lebih efektif. Media pembelajaran merupakan salah satu komponen dalam belajar karena media perlu diintegrasikan dengan komponen pendukung lainnya agar mudah dalam pengelolaan dan pemanfaatannya (Nafi'a, 2020) selain itu media pembelajaran yang baik dan sesuai harus dikembangkan secara adaptif sesuai dengan keunikan gaya belajar para pengguna ( Surahman, Wedi, Soepriyanto, \& Setyosari, 2018).

Pada hasil observasi yang dilakukan di SDN 3 Klagen Rejoso, Pembelajaran di kelas masih menggunakan metode konvensional, guru hanya berpedoman pada buku cetak dan LKS saat mengajar, untuk minat dan antusiasme siswa ketika belajar masih minim, hal itu diperjelas dengan usulan guru yang mengajar untuk membuat media yang dapat memberikan rasa ingin tau siswa saat diajar lebih meningkat, karena selama ini penggunaan media hanya menggunakan papan tulis dan buku paket atau LKS saja. Dalam pernyataan (Afdhal, 2016) terdapat ungkapan yang mengartikan bahwa penting untuk menjaga rasa antusiasme belajar siswa dengan memadukan ketertarikan pribadi siswa dengan kurikulum yang dibuat oleh guru. Ketika merencanakan suatu pembelajaran, guru seharusnya tidak terpaku pada ketuntasan belajar yang hanya berdasarkan kurikulum, tetapi guru sebaiknya harus memperhatikan juga ketertarikan siswa terhadap materi yang dipelajari dengan menggunakan media agar bisa meningkatkan rasa semangat belajarnya.

Berdasarkan tujuan masalah dari pengembangan ini ialah untuk menghasilkan produk media yang layak, serta dapat digunakan sebagai perantara dalam mengetahui adanya perubahan antusiasme siswa 
dalam belajar antara sebelum dan sesudah menggunakan media. Dengan demikian adanya media multimedia linier diharapkan dapat memudahkan proses penyampaian materi kepada siswa, mampu menarik perhatian siswa, menumbuhkan antusias dan motivasi belajar siswa dalam pembelajaran

\section{METODE}

Model yang akan digunakan dalam penelitian ini ialah menggunakan metode penelitian dan pengembangan (Research and Development). Pada penelitian dan pengembangan yang akan dikembangakan yaitu menggunakan model (Lee \& Owens, 2004) dengan beberapa tahapannya yaitu analisis (Analysis), desain (Design), pengembangan (Development), implementasi (Implementation) dan evaluasi (Evaluation). Berikut adalah tahapan prosedur penelitian dan pengembangan yang digunakan.

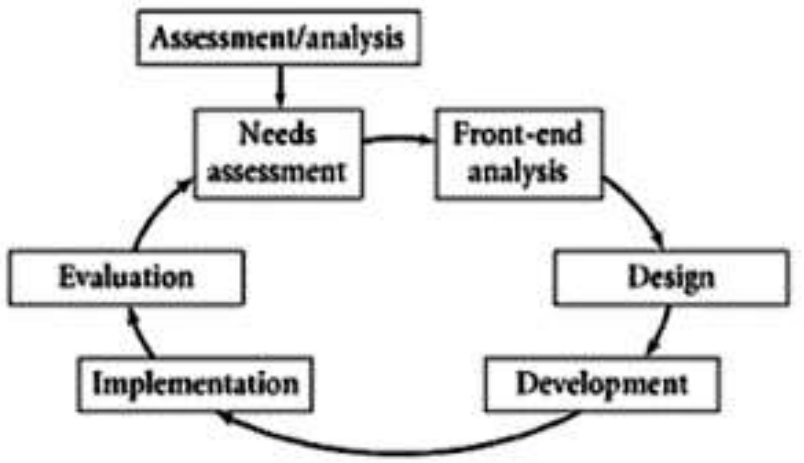

Gambar 1. Prosedur Pengembangan Model Lee \& Owens (2004)

Pengembangan ini hanya dilakukan sampai tiga tahapan dengan alasan multimedia pembelajaran hanya mengembangkan sampai tahap produk yang bertujuan untuk mengukur tingkat kelayakan dari media yang dikembangkan. Berikut tahapan yang digunakan ialah: 1) tahap assessment/analisis yang terdiri dari dua tahap Need Assessment dan front-end analysis, 2) tahap desain, 3) tahap pengembangan. Sedangkan pada tahap implementasi dan evaluasi tidak dilakukan dengan alasan multimedia linier yang dikembangkan masih dalam uji coba kesiapan teknologi dan pengembangan produk.

Uji coba produk akan dilakukan kepada ahli media, ahli materi dan siswa. Instrument yang digunakan adalah angket respon atau tanggapan ahli media, ahli materi dan siswa dengan kisi-kisi yang telah disiapkan. Angket media untuk para ahli serta angket media dan antusiasme belajar untuk siswa sama-sama menggunakan rating scale dengan rentang nilai 4,3,2,1. Angket respon yang telah terisi oleh ahli yang telah ditunjuk memberikan gambaran tentang kelayakan media yang akan dikembangkan. Kemudian media dapat digunakan dalam proses pembelajaran kepada siswa agar dapat memberikan perubahan positif terhadap antusiasme belajarnya.

\section{HASIL}

Tahap pertama ialah analisis yang meliputi kebutuhan dan analisis awal dan akhir. Pada analisis kebutuhan, hasil dari observasi dan wawancara di SD Negeri Klagen 3 Rejoso guru kelas memerlukan media pembelajaran yang dapat memudahkan siswa dalam memahami pelajaran dan membantu menumbuhkan antusias siswa saat belajar. Atas saran dari guru yang bersangkutan, materi yang cocok menggunakan media ialah pada tema 6 yang mempelajari tentang panas dan perpindahannya. Berhubung sekolahan yang bersangkutan sudah memiliki fasilitas berupa LCD maka dapat mempermudah proses pembelajaran lebih efektif dengan menggunakan fasilitas yang telah ada.

Kegiatan kedua ialah analisis awal dan akhir meliputi analisis audiens yang diterapkan pada siswa kelas V SD Negeri Klagen 3 Rejoso Nganjuk yang ber jumlah 14 siswa dalam 1 kelas. Selanjutnya kegiatan analisis teknologi , rata-rata siswa ada yang belum mampu mengoperasikan laptop dan tidak adanya fasilitas komputer dari sekolah tersebut, sehingga lebih cocok apabila media yang akan digunakan menggunakan multimedia linier yang berupa video pembelajaran, karena lebih tepat dan 
sesuai dengan kebutuhan. Kegiatan ketiga yaitu analisis situasi. Dalam hal ini kegiatan belajar mengajar sebelum terjadinya pandemi sudah berjalan dengan baik. Lokasi sekolah sangat sepi karena terletak di anatara sawah dan rumah warga yang berjarak-jarak, sehingga tidak terganggu suara-suara kendaraan. Kegiatan keempat analisis task. Pengembang memberikan siswa file media pembelajaran yang berupa soft multimedia linier yang dapat dimanfaatkan siswa apabila mempelajari kembali saat di rumah dengan menggunakan smartphone. Kegiatan kelima analisis kejadian penting. Pada tahap ini media yang digunakan menyediakan multimedia linier berupa manfaat perpindahan suhu dan kalor terhadap kehidupan sehari-hari yang disajikan berupa animasi, sehingga diperlukan dalam penggunaan media. Kegiatan keenam analisis masalah. Dari identifikasi pada observasi di SD Negeri 3 Klagen Rejoso Nganjuk, pengembang tidak menemukan masalah dalam hal mengembangkan media, tetapi masih perlu adanya guru yang mendamping agar siswa tetap terkontrol. Kegiatan ketujuh analisis tujuan. Adapun tujuan dari pengembangan adalah menghasilkan media yang layak yang dapat meningkatkan antusiasme belajar siswa. Kegiatan kedelapan analisis media. Jenis media yang digunakan adalah berformat mp4 yang dapat ditampilkan pada LCD melalui laptop. Media yang dikembangkan menggunakan Microsoft Power Point, Adobe Premier dan Adobe Ilustrator. Kegiatan kesembilan analisis data. Produk multimedia linier pembelajaran ini berpusat pada tema 6 materi panas dan perpindahannya yang didapat dari buku dan LKS yang sesuai dengan kurikulum 2013. Kegiatan kesepuluh analisis biaya. Pada tahap ini tidak dijelaskan secara rinci mengenai biaya yang diperlukan.

Pada tahap kedua ialah desain. Desain dilakukan dalam pembuatan produk, Hal ini diungkapkan oleh (Bonk \& Graham, 2012) Pada tahap desain pengembang melakukan kegiatan seperti perancangan produk, penyusunan materi dan alat evaluasi seperti kegiatan perancangan produk pembuatan Story Board, pembuatan RPP, silabus, pengumpulan gambar, rekaman audio, membuat beberapa gerakan animasi dan Instrument yang digunakan untuk mengukur kualitas multimedia linier dengan menggunakan angket. Angket diberikan kepada ahli media, materi dan siswa. sedangkan untuk mengukur antusiasme belajar siswa yaitu dengan angket pernyataan yang sesuai dengan kondisi siswa ketika sebelum dan sesudah menggunakan media.

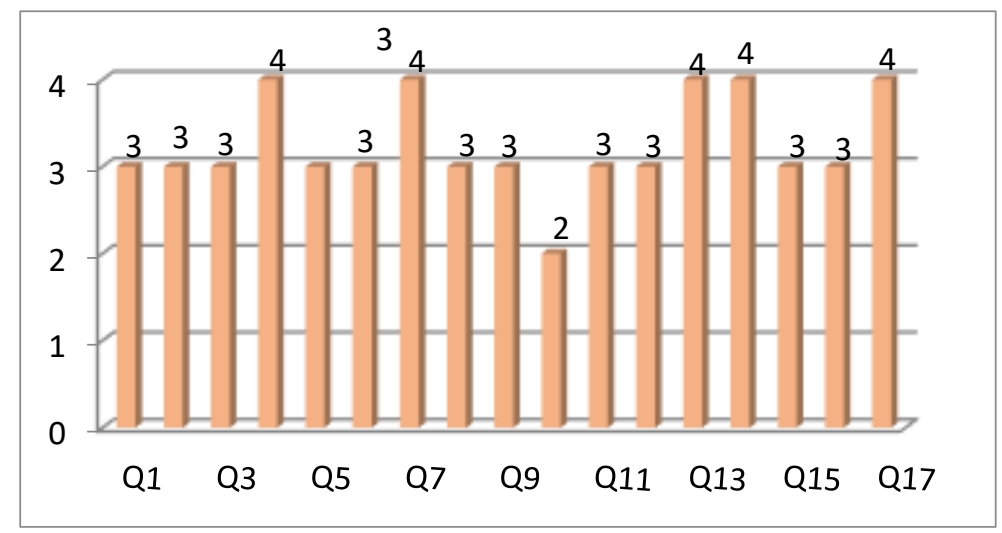

Gambar 2. Diagram hasil review Ahli media

Tahap ketiga ialah pengembangan, dimana kegiatan ini memproduksi Multimedia Linier pembelajaran dengan menggunakan format $\mathrm{mp} 4$, mengembangkan elemen-elemen yang telah disusun, dilanjutkan dengan penilaian media kepada para ahli, yaitu ahli media dan ahli materi. Setelah di review dan terdapat revisi, maka media segera diperbaiki sesuai saran dari para ahli hingga mendapat penilaian media yang layak digunakan kepada siswa.

Berdasarkan gambar 2 hasil angket ahli media dapat dilihat dari Aspek penyajian yang terdiri dari aspek tampilan grafis, keefektifan dan isi dari media. Hasil penyajian dari 17 pernyataan diatas terdapat 5 pernyataan mendapat nilai 4,11 pernyataan mendapat nilai 3 dan 1 pernyataan dengan nilai 
2. Dari nilai yang didapatkan pada grafik diatas ahli media memberikan saran perbaikan pada bagian audio untuk diperjelas lagi sedangkan untuk komponen-komponen lainnya tidak ada perbaikan.

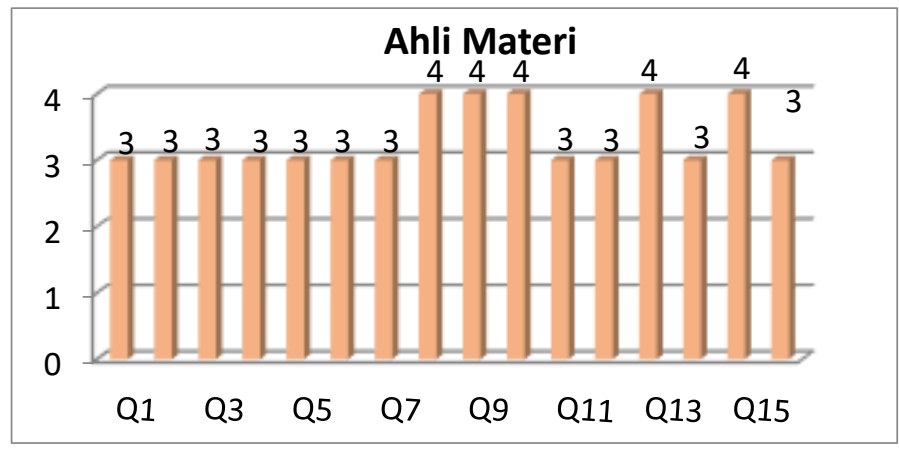

\section{Gambar 3. Diagram hasil review Ahli materi}

Berdasarkan gambar 3, hasil angket ahli materi terhadap Aspek penyajian yang digunakan terdiri dari aspek Isi pembelajaran, kebahasaan, dan penulisan materi. Hasil penyajian dari 16 pernyataan diatas terdapat 5 pernyataan dengan nilai 4, dan 11 pernyataan dengan nilai 3. Mayoritas penilaian terbanyak di dapatkan pada nilai 3. Ahli materi memberi saran perbaikan untuk mencantumkan profil pengembang, mencantumkan standar kompetensi dan sedikit perbaikan pada bagian animasinya. Dengan demikian kedua tanggapan dari hasil review para ahli menunjukkan bahwa multimedia linier pembelajaran telah layak dengan respon positif dalam memberikan saran perbaikan agar menjadi media pembelajaran yang lebih sesuai dan bermanfaat saat digunakan oleh siswa.

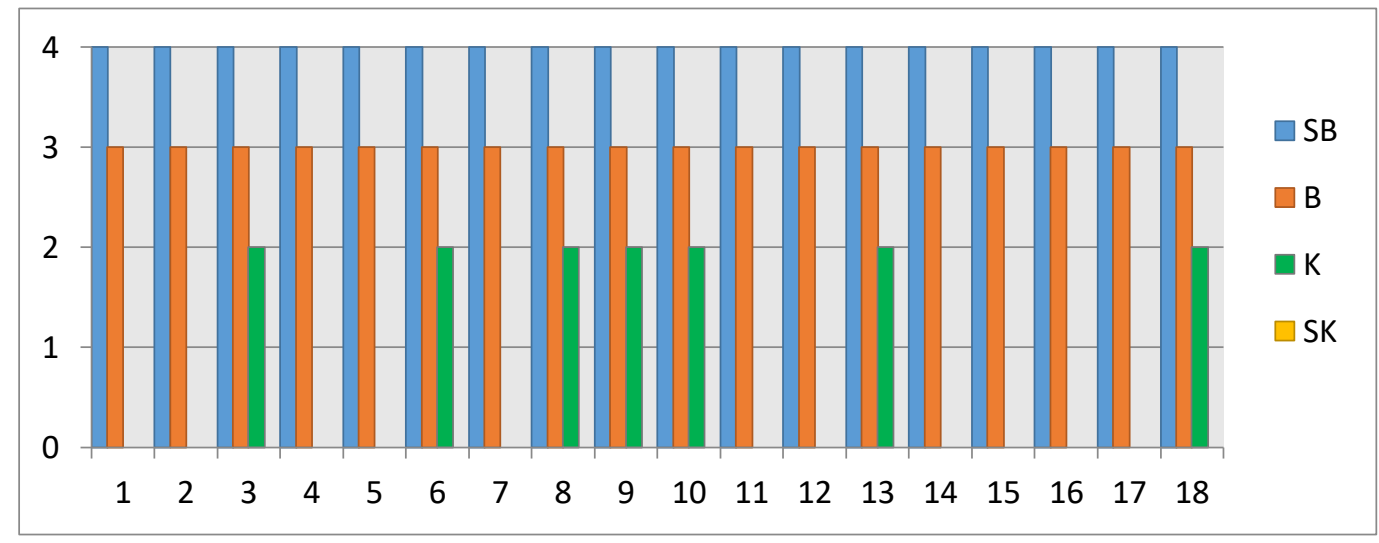

Gambar 4. Diagram hasil tanggapan siswa

Selanjutnya dapat dilihat Pada gambar 4, hasil ujicoba media pembelajaran multimedia linier yang dilakukan oleh 14 siswa dengan jumlah pernyataan 18 dan terdiri dari indikator aspek tampilan, efektifitas dan isi. Pada pertanyaan soal 1,2,4,5,7,11,13,14,15,16,dan 17 rata-rata siswa memilih jawaban sangat baik dan baik. Sedangkan pada soal 3,6,8,9,10,13, dan 18 siswa memilih jawaban sangat baik, baik, dan beberapa memilih jawaban kurang terhadap pengisian angket media yang telah disediakan. Dalam ujicoba media terdapat beberapa siswa menyampaikan pendapatnya bahwa media multimedia linier ini sudah bagus, mudah dipahami, gambarnya menarik dan tulisannya mudah dibaca, dan bisa memberikan suasana kelas menjadi lebih antusias karena teman-teman terlihat konsentrasi ketika melihat media ditampilkan.

Konsentrasi belajar adalah salah satu aspek antusiasme. Antusiasme siswa adalah sikap positif yang harus dimiliki oleh siswa agar dapat terhubung saat proses pembelajaran yang diberikan oleh guru. Antusiasme yang peneliti gunakan ialah terdiri dari beberapa indikator. Indikator antusiasme pertama yaitu pada kemampuan mengenai pengetahuan siswa terdapat pada soal pertanyaan 1-4 dengan nilai scale keseluruhan terdapat 1 hingga 4 dari jumlah 18 pernyataan dan mengalami peningkatan sebesar 
5.36, Indikator antusiasme kedua yaitu pada kesadaran siswa terdapat pada soal pertanyaan 5-7 dengan nilai keseluruhan 4,3,2 dan peningkatannya sebesar 1.19. Indikator antusiasme ketiga yaitu pada keterlibatan diri siswa terdapat pada soal pertanyaan 8-11 yang mengalami peningkatan sebesar 10.85, Indikator antusiasme keempat yaitu pada konsentrasi siswa saat belajar terdapat pada soal pertanyaan 12-15 yang mengalami peningkatan paling besar dengan 11.6, Indikator antusiasme kelima yaitu pada perhatian siswa terdapat pada soal pertanyaan 16-18 dengan peningkatan sebesar 10.14. Untuk indikator yang terendah terdapat pada kesadaran, sedangkan indikator yang tertinggi ada pada indikator konsentrasi yaitu dari 68.75 menjadi 80.35 dengan peningkatan presentase sebesar 11.6 untuk melihat perbandingan peningkatan antusiasme secara signifikan dapat dilihat pada grafik dibawah ini:



Gambar 5. Perbandingan peningkatan antusiasme belajar

Berdasarkan gambar 5 dapat dilihat pada tahap sebelum dan sesudah, rata-rata hasil antusiasme belajar siswa mengalami peningkatan dari awalnya $70 \%$ menjadi $82.94 \%$ dengan peningkatan nilai 12.94\%. Dengan demikian penggunaan media dalam belajar sangat diperlukan untuk menunjang antusiasme siswa ketika belajar.

\section{PEMBAHASAN}

Dalam proses menambah pengetahuan saat pembelajaran, biasanya guru memiliki beragam metode pelajaran yang harus di kuasai, salah satu metode yang sering digunakan adalah metode Konvesional dengan menggunakan papan tulis. Untuk zaman pendidikan sekarang pembelajaran yang hanya mengandalkan papan tulis saja tidaklah cukup untuk memberikan pengetahuan kepada para siswa yang beda generasi saat ini. Oleh karena itu guru diperlukan dalam memahami setiap Karakteristik siswa yang telah diungkapan oleh (Septianti\& Afiani, 2020) bahwa Karakteristik siswa sangat penting untuk diketahui oleh para pendidik, karena ini sangat penting untuk dijadikan tumpuan dalam merumuskan strategi pengajaran. Tidak hanya dalam strategi pembelajaran saja, Guru juga perlu beralih menggunakan pembelajaran inovatif dengan menggunakan beragam media pembelajaran yang lebih modern. Sesuai dengan ungkapan (Kesumadewi \& Rati, 2020) Perlu adanya inovasi yang berbeda dari biasanya agar pembelajaran dapat menggugah semangat belajarnya siswa.

Dalam hal ini inovasi yang menggugah ialah dengan menggunakan Multimedia Linier. Penggunaan Multimedia Linier ini sangat mudah, cukup dioperasikan dalam sekali tahapan. Menurut hasil review ahli media dan ahli materi terhadap penggunaan multimedia linier ialah sesuai dan bisa digunakan untuk penambahan materi saat proses belajar. Review dari ahli media pada penyajian angket yang digunakan terdiri dari aspek tampilan grafis, keefektifan dan isi dari media. Hasil penyajian dari 17 pernyataan, terdapat 5 pernyataan mendapat nilai 4,11 pernyataan mendapat nilai 3 dan 1 pernyataan dengan nilai 2. Dari nilai yang didapatkan pada hasil diatas ahli media memberikan saran perbaikan pada bagian audio untuk diperjelas lagi sedangkan untuk komponen-komponen lainnya tidak ada perbaikan. Sedangkan pada hasil review ahli materi, penyajian angket yang digunakan terdiri dari aspek Isi pembelajaran, kebahasaan, dan penulisan materi. Hasil penyajian 16 pernyataan terdapat 5 pernyataan dengan nilai 4, dan 11 pernyataan dengan nilai 3 . Mayoritas penilaian terbanyak di dapatkan 
pada nilai 3. Ahli materi memberi saran perbaikan untuk mencantumkan profil pengembang, mencantumkan standar kompetensi dan sedikit perbaikan pada bagian animasinya.

Untuk hasil ujicoba media yang dilakukan oleh siswa terdiri dari 18 pernyataan dengan indikator aspek tampilan, efektifitas dan isi. Pada gambar 4 telah diperjelas untuk soal pernyataan 1,2,4,5,7,11,13,14,15,16,dan 17 siswa memilih interpretasi nilai dengan sangat baik dan baik. Sedangkan pada soal pernyataan 3,4,8,9,10,13, dan 18 beberapa siswa memilih nilai interpretasi sangat baik, baik dan kurang. Sebagian besar siswa memilih indikator tampilan dengan nilai 4 dan 3, sedangkan pada indikator efektifitas dan isi sebagian siswa memilih nilai 4,3 dan 2 untuk setiap pernyataannya. Sehingga dapat disimpulkan mayoritas siswa memilih nilai 4 dengan interpretasi sangat baik.

Setelah mengembangkan multimedia linier yang layak, Tujuan selanjutnya ialah untuk mengetahui apakah terdapat peningkatan antusiasme belajar siswa antara sebelum dan sesudah penggunaan media. Setelah di ujicobakan kepada siswa melalui angket, analisis antusiasme belajar siswa dengan menggunakan Multimedia Linier pada Indikator pertama yaitu pada kemampuan mengenai pengetahuan siswa terdapat pada soal pertanyaan nomor 1-4 dengan nilai scale keseluruhan terdapat 1 hingga 4 dari jumlah 18 pernyataan dan mengalami peningkatan sebesar 5.36, Indikator antusiasme kedua yaitu pada kesadaran siswa terdapat pada soal pertanyaan 5-7 dengan nilai keseluruhan 4,3,2 dengan peningkatan sebesar 1.19, Indikator antusiasme ketiga yaitu pada keterlibatan diri siswa terdapat pada soal pertanyaan 8-11 yang mengalami peningkatan sebesar 10.85, berhubung denga keterlibatan diri dorongan itu dapat timbul dari dalam diri subjek yang bersumber dari usaha yang dilakukan secara sadar untuk merubah sikap dan tingkah lakunya (Emda, 2018) sehingga beberapa siswa memberanikan diri untuk bertanya ketika ada materi yang kurang dipahaminya , Indikator antusiasme keempat yaitu pada konsentrasi siswa saat belajar terdapat pada soal pertanyaan 12-15 yang mengalami peningkatan paling besar dengan 11.6, indikator antusiasme kelima yaitu pada perhatian siswa terdapat pada soal pertanyaan 16-18 dengan peningkatan sebesar 10.14 sesudah menggunakan media. Dalam ujicoba media terdapat beberapa siswa menyampaikan pendapatnya bahwa media multimedia linier ini sudah bagus, mudah dipahami, gambarnya menarik dan tulisannya mudah dibaca, dan bisa memberikan suasana kelas menjadi lebih antusias karena teman-teman terlihat konsentrasi ketika melihat media ditampilkan.

Berdasarkan penelitian yang pernah dilakukan oleh (Nugroho, 2015) menunjukkan adanya efek positif dan signifikan sikap siswa terhadap penggunaan media pembelajaran berupa video. Sama halnya dengan penggunaan multimedia linier pembelajaran dalam memberikan efek antusiasme siswa sehingga mampu memahami materi yang diberikan. Hasil wawancara pada pernyataan (Pradipta et al., 2016) menunjukkan video tersebut dapat memudahkan siswa untuk memahami dan mengingat materi dalam belajar. Sesuai dengan ungkapan (Pramudito, 2013) penggunaan media pembelajaran video akan mempermudah dan membantu proses pembelajaran tanpa memikirkan ruang dan waktu yang sangat terbatas, karena dengan penggunaan video mampu memanipulasi waktu dan memanipulasi ruang serta mampu mengembangkan imajinasi siswa dalam berpikir.

Sejalan dengan penelitian (Wooting,2014) media video sangat berpengaruh terhadap hasil belajar dan keterampilan siswa dalam berinteraksi. Dengan menggunakan video maka suasana belajar bertambah menyenangkan dan tidak membosankan (Hardianti \& Asri, 2017).

Penggunaan video dalam pembelajaran, secara tidak langsung mampu menumbuhkan motivasi dan antusiasme kepada peserta didik. Selain itu penggunaan media video mampu membuat siswa fokus selama proses pembelajaran berlangsung (Rahayu, Hadiarti, \& Kurniati, 2018). Dalam penelitian (Chayuda\& Basri, 2017) terdapat hubungan penggunaan multimedia linier yang mampu memberikan pengaruh positif terhadap motivasi belajar siswa. Maka disini bisa dilihat antara Multimedia Linier dengan sikap yang dilakukan siswa bisa berpengaruh terhadap minat dan antusiasme belajar siswa, karena dengan penggunaan Multimedia Linier dapat mengurangi kebosanan siswa yang selalu melihat 
teks dari buku saja. Hal ini dapat diperkuat dari penelitian (Nashrullah, Sulton, \& Soepriyanto, 2019) yang memaparkan bahwa penggunaan multimedia linier sama halnya seperti Video pembelajaran yang berfungsi untuk menghilangkan verbalisme (kata-kata) pada buku/LKS yang terlalu banyak, karena video pembelajaran dapat menvisualisasikan materi pelajaran atau pesan yang ingin disampaikan dalam pembelajaran. pembuatan media video lebih mengedepankan visual dan menjadikan pesan lebih mudah dipahami dengan lebih cepat (Siang, Hasan, \& Tamhir, 2019). Video pembelajaran dapat mempermudah siswa mengulang materi sampai mengerti, apabila siswa kurang paham dengan materi yang disampaikan guru (Permatasari, Degeng, \& Adi, 2019).

Berkenaan dengan menumbuhkan antusiasme belajar di kelas, kesuksesan dalam belajar akan mudah tercapai ketika guru membuat perencanaan mengajar yang terorganisir, sehingga mampu menumbuhkan sikap ketertarikan dan minat dalam belajar siswa (Zendrato,2016). Antusiasme dapat dilakukan dengan cara melibatkan siswa dengan sebuah tantangan dan partisipasi yang dapat berpengaruh positif terhadap akademisnya (Skinner\& Pitzer, 2012). Sama halnya pada ungkapan (Pliskin, 2002) yang menyatakan bahwa antusiasme dalam belajar akan membuat pemahaman siswa terhadap permasalahan yang dipelajari akan lebih baik dan bertahan lama. Siswa yang antusias dalam belajar akan cenderung menikmati setiap proses yang mereka lalui dalam kegiatan belajar mengajar. Semakin tinggi antusiasme belajar siswa, maka kemungkinan besar untuk mencapai prestasi yang tinggi juga akan semakin besar.. Siswa yang antusias juga memiliki kemauan yang kuat untuk ikut aktif dalam kegiatan pembelajaran (Afdhal \& Sugiman, 2017). Jadi, antusiasme belajar merupakan salah satu sikap positif yang wajib ditumbuhkan saat pembelajaran berlangsung. Melalui Multimedia Linier siswa akan lebih tertarik, sehingga mampu membuat siswa lebih antusias dan termotivasi dalam mendengarkan dan berkonsentrasi terhadap apa yang ia lihat. Hal itu dinyatakan oleh (Moss, 2015) bahwa antusiasme merupakan kecakapan hidup yang dapat dikembangkan dengan cara mengelola konsep dan teknik pembelajaran yang baik, sehingga diperlukanya sikap kinerja seorang guru yang kompoten dan menyenangkan, karena cara mengajar siswa sangat berpengaruh terhadap pembentukan sikap siswa saat belajar (Mensah, Okyere\&Kuranchie, 2013).

\section{SIMPULAN}

Kesimpulan yang didapatkan dari hasil review ahli media dan ahli materi menunjukkan adanya penilaian positif dari segi saran dan perbaikan tambahan yang diberikan. Secara keseluruhan desain multimedia linier sudah baik. Adapun tambahan dari ahli media ialah suara narationnya lebih diperjelas, sedangkan tambahan dari ahli materi adalah mencantumkan standar kompetensi, profil pengembang dan penambahan animasi agar lebih terlihat hidup. Semua saran dan masukan tersebut akan ditambahkan pada multimedia linier agar produk menjadi lebih baik. Kelebihan dalam pengembangan multimedia linier ini adalah memberikan kemudahan siswa dalam memahami materi dan mampu memberikan peningkatan antusiasme dan motivasi siswa agar belajarnya lebih bersemangat. Berdasarkan hasil pengolahan data dan kriteria yang telah dijabarkan, diketahui bahwa multimedia linier yang dikembangkan termasuk dalam kriteria yang dapat digunakan dalam proses pembelajaran. Sedangkan untuk kedepannya, diharapkan multimedia linier bisa dikembangkan lebih baik lagi dalam menunjang kebutuhan belajar siswa.

\section{DAFTAR RUJUKAN}

Afdhal. M, (2016). Pengembangan Perangkat Pembelajaran Matematika SMP Kelas VIII Semester Genap Berbasis Reciprocal Teaching Berorientasi Pada Prestasi Belajar, Kemampuan Berpikir Kritis Matematis Dan Antusiasme Belajar Peserta didik. Yogyakarta: UNY

Afdhal, M., \& Sugiman, S. (2017). Pengembangan perangkat pembelajaran berbasis reciprocal teaching berorientasi pada antusiasme dan kemampuan berpikir kritis siswa. Pythagoras: Jurnal Pendidikan Matematika, 12(2), 173-186. 
Chayuda, M. R., \& Basri, M. (2017). Hubungan Antara Media Berbasis Multimedia Linier Dengan Motivasi Belajar Siswa. PESAGI (Jurnal Pendidikan dan Penelitian Sejarah), 5(7).

Emda, A. (2018). Kedudukan motivasi belajar siswa dalam pembelajaran. Lantanida Journal, 5(2), 172182.

Hardianti, H., \& Asri, W. K. (2017). Keefektifan Penggunaan Media Video Dalam Keterampilan Menulis Karangan Sederhana Bahasa Jerman Siswa Kelas Xii Ipa Sma Negeri 11 Makassar. Eralingua: Jurnal Pendidikan Bahasa Asing dan Sastra, 1(2).

Kesumadewi, D. A., Agung, A. A. G., \& Rati, N. W. (2020). Model Pembelajaran CIRC Berbantuan Media Cerita Bergambar Meningkatkan Hasil Belajar Bahasa Indonesia Siswa SD. MIMBAR PGSD Undiksha, 8(2), 303-314.

Lee.W.W. \& Owen. D. L. (2004). Multimedia based instructional design, second edition

Mensah, J. K., Okyere, M., \& Kuranchie, A. (2013). Student attitude towards mathematics and performance: Does the teacher attitude matter. Journal of education and practice, 4(3), 132-139.

Moss, B. (2015). The enthusiasm-laffter connection. Bloomington: iUniverse.

Nafi'a, M. Z. I., Degeng, I. N. S., \& Soepriyanto, Y. (2020). Pengembangan Multimedia Interaktif Materi Perkembangan Kemajuan Teknologi Pada Mata Pelajaran Ilmu Pengetahuan Sosial. Jurnal Kajian Teknologi Pendidikan, 3(3), 272-281.

Nashrullah, N., Sulton, S., \& Soepriyanto, Y. (2019). Pengembangan Video Pembelajaran Adaptasi Dan Cara Berkembang Biak Makhluk Hidup Untuk Siswa Kelas Vi Sekolah Dasar. Jurnal Kajian Teknologi Pendidikan, 1(4), 327-332.

Nugroho, T. A. T. (2015). Pengaruh Penggunaan Media Video Pembelajaran terhadap Keterampilan Proses IPA dan Hasil Belajar IPA pada Siswa Kelas V SD Negeri Rejowinangun 1 Yogyakarta Tahun Ajaran 2014/2015. Skripsi, Universitas Negeri Yogyakarta, PGSD, Yogyakarta.

Nurseto, T. (2011). Membuat media pembelajaran yang menarik. Jurnal Ekonomi dan pendidikan, 8(1).

Permatasari, K., Degeng, I. N. S., \& Adi, E. P. (2019). Pengembangan Suplemen Video Pembelajaran Adaptasi Makhluk Hidup untuk Siswa Tunarungu SLB-B YPLB Blitar. Jurnal Kajian Teknologi.... Retrieved from http://journal2. um. ac. id/index. php/jktp/article/view/268.

Pliskin, R. Z. (2002). Enthusiasm: formula, stories and insights. Brooklyn: Shaar Press.

Porlzline, L. (2012). Follow your enthusiasm. New York, NY: Williamsport PA.

Pradipta, P. C., \& Ghani, A. A. (2016). Media Video Kejadian Fisika di Lingkungan Disertai Besaran Fisis dalam Pembelajaran Fisika di SMA (Studi Pada Kelas X SMA Negeri 1 Muncar). Jurnal Pembelajaran Fisika, 4(4), 331-337.

Pramudito, A. (2013). Pengembangan media pembelajaran video tutorial pada mata pelajaran kompetensi kejuruan standar kompetensi melakukan pekerjaan dengan mesin bubut di SMK Muhammadiyah 1 Playen. Jurnal Pendidikan Teknik Mesin, 1(1), 1-12.

Rahayu, E. T., Hadiarti, D., \& Kurniati, T. (2018). Pengembangan Video Pembelajaran Pada Materi Ekstraksi Dan Isolasi Senyawa Metabolit Sekunder Daun Buas-Buas (Premna Serratifolia Linn) Di Program Studi Pendidikan Kimia Universitas Muhammadiyah Pontianak. AR-RAZI Jurnal Ilmiah, 6(1).

Septianti, N., \& Afiani, R. (2020). Pentingnya Memahami Karakteristik Siswa Sekolah Dasar di SDN Cikokol 2. AS-SABIQUN, 2(1), 7-17. 
Siang, J. L., Hasan, B., \& Tamhir, L. (2019). Video Development as Supporting Learning Media for Teachers at SMP Negeri 5 Tidore Islands [Pengembangan Video Sebagai Penunjang Media Pembelajaran Bagi Guru di SMP Negeri 5 Tidore Kepulauan]. Proceeding of Community Development, 2, 111-118.

Skinner, E. A., \& Pitzer, J. R. (2012). Developmental dynamics of student engagement, coping, and everyday resilience. In Handbook of research on student engagement (pp. 21-44). Springer, Boston, MA.

Sumiah, S. (2012). Peningkatan Antusias Belajar Ilmu Pengetahuan Alam Melalui Penerapan Model Pq4r (Preview, Question, Read, Reflect, Recite, Review) Pada Siswa Kelas IV Semester I SDN Sukolilo 04 Tahun Pelajaran 2012/2013 (Doctoral dissertation, Universitas Muhammadiyah Surakarta).

Surahman, E., Wedi, A., Soepriyanto, Y., \& Setyosari, P. (2018, December). Design of Peer Collaborative Authentic Assessment Model Based on Group Project Based Learning to Train Higher Order Thinking Skills of Students. In International Conference on Education and Technology (ICET 2018). Atlantis Press.

Woottipong, K. (2014). Effect of using video materials in the teaching of listening skills for university students. International Journal of Linguistics, 6(4), 200.

Zendrato, J. (2016). Tingkat penerapan rencana pelaksanaan pembelajaran dalam pelaksanaan pembelajaran di kelas suatu studi kasus di SMA Dian Harapan Jakarta. Scholaria: Jurnal Pendidikan Dan Kebudayaan, 6(2), 58-73. 